\title{
Validitas model pembelajaran IDEA (Issue, Discussion, Establish, and Apply) untuk meningkatkan pemahaman konsep
}

\author{
Yayan Eryk Setiawan, Mustangin \\ Pendidikan Matematika, Fakultas Keguruan dan Ilmu Pendidikan, Universitas Islam Malang, Indonesia \\ E-mail: yayaneryksetiawan@unisma.ac.id
}

\begin{abstract}
ABSTRAK
Salah satu hal penting dalam pembelajaran matematika adalah menekankan pemahaman konsep. Namun, kesalahan konsep dalam menyelesaikan masalah matematika masih umum ditemukan. Salah satu solusi yang dapat dilakukan untuk mengatasi kesalahan konsep adalah mengembangkan model pembelajaran untuk meningkatkan pemahaman konsep. Penelitian ini bertujuan untuk mengembangkan model pembelajaran yang dapat meningkatkan pemahaman konsep. Model pembelajaran yang dikembangkan dalam penelitian ini disebut model pembelajaran IDEA (Issue, Discussion, Establish, and Apply). Setelah berhasil dirancang, validitas model pembelajaran IDEA diuji. Tes validitas model pembelajaran IDEA dilakukan oleh 2 ahli dan 1 praktisi. Hasil uji validitas model pembelajaran IDEA menunjukkan bahwa model pembelajaran IDEA valid dan dapat digunakan untuk meningkatkan pemahaman konsep.
\end{abstract}

Kata kunci: model pembelajaran IDEA; Validitas model Pembelajaran; Pemahaman Konsep

\begin{abstract}
One of the important things in learning mathematics is to emphasize understanding of concepts. However, concept errors in solving mathematical problems are still commonly found. One solution that can be done to overcome the concept errors is to develop a learning model to improve concept understanding. This research aims to develop a learning model that can improve concept understanding. The learning model developed in this study is called the IDEA learning model (Issue, Discussion, Establish, and Apply). After successfully designed, the validity of the IDEA learning model was tested. The validity test of the IDEA learning model is conducted by 2 experts and 1 practitioner. The validity test results of the IDEA learning model show that the IDEA learning model is valid and can be used to improve understanding of concepts.
\end{abstract}

Keywords: IDEA learning model; Validity of the Learning model; Concept Understanding

\section{PENDAHULUAN}

Konsep didefinisikan sebagai ide abstrak yang merupakan hasil abstraksi dari hal-hal konkret. Pembelajaran matematika penting untuk memulai dengan memahamkan suatu konsep kepada siswa atau mahasiswa. Seperti yang disampaikan oleh Mills (2019) yang mengatakan bahwa pemahaman konsep merupakan awal dari pemahaman prosedur. Selain itu, pentingnya pemahaman konsep disampaikan di awal pembelajaran adalah konsep yang sudah dipahami digunakan untuk membangun konsep-konsep lain, karena dalam matematika terdapat konsep yang harus dibangun dari konsep lain (Setiawan, 2019). Misalnya konsep tentang jarak yang dibangun dari konsep teorema Pythagoras. Jadi sangat penting dalam pembelajaran matematika untuk menekankan pemahaman konsep.

Akan tetapi berbagai penelitian menunjukkan bahwa siswa maupun mahasiswa masih mengalami berbagai kesalahan konsep. Misalnya penelitian Setiawan dan Sunardi (2016) yang menunjukkan bahwa kesalahan-kesalahan siswa SMP dalam menjawab soal disebabkan 
kurang teliti dan kurang memahami materi yang sedang dipelajari. Hasil penelitian Setiawan, Purwanto, Parta, dan Sisworo (2020) yang juga menunjukkan bahwa kesalahan yang dilakukan siswa SMP juga dipengaruhi oleh gaya kognitif, terutama dalam hal ketelitian dan perhatian. Hasil studi pendahuluan terhadap 33 mahasiswa dalam menyelesaikan masalah soal pemahaman konsep diperoleh $72,27 \%$ mahasiswa salah dalam menyatakan kembali konsep sudut yang sudah dipelajari. Hasil penelitian lain juga menunjukkan masih banyak kesalahan konsep yang dilakukan oleh mahasiswa, antara lain penelitian (Adna, 2017; Afifah, Nafi'an, \& Putri, 2018; Afriadi, 2019; Arvianto, 2017; Fachrurrozy, Muslimin, \& Saehana, 2017; Farhan \& Zulkarnain, 2019; Jana, 2018; Lembang \& Ba'ru, 2018; Lusiana, 2017; Oktaviana, 2018; Rosmaiyadi, 2018). Jadi masih banyak ditemukan kesalahan konsep dalam menyelesaikan masalah matematika.

Kesalahan konsep dari siswa maupun mahasiswa tidak lepas dari pengaruh guru atau dosen dalam melakukan pembelajaran. Hal ini dikarenakan kemampuan guru atau dosen akan mempengaruhi pembelajaran dan pada akhirnya pembelajaran akan mempengaruhi prestasi belajar siswa maupun mahasiswa (Setiawan, 2015). Ini artinya pengaruh dari seorang guru atau dosen sangat besar terhadap prestasi siswa maupun mahasiswa. Sebagai upaya solusi untuk mengatasi kesalahan konsep, maka peneliti mencoba mengembangkan suatu model pembelajaran yang dapat digunakan untuk meningkatkan atau mengembangkan pemahaman konsep. Model pembelajaran ini adalah model pembelajaran IDEA (Issue, Discussion, Establish, and Apply).

Model pembelajaran IDEA ini didefinisikan sebagai rencana atau pola yang digunakan untuk merancang materi pembelajaran dan untuk membimbing pembelajaran di kelas yang berbasis pada empat kegiatan, yaitu Issue, Discussion, Establish, dan Apply. Fungsi jangka pendek dari model pembelajaran IDEA ini adalah membantu siswa maupun mahasiswa untuk memperoleh informasi tentang konsep dan cara berpikir yang sistematis dalam memahami suatu konsep dalam matematika. Sedangkan fungsi jangka panjang dari model pembelajaran IDEA ini adalah membuat siswa atau mahasiswa terbiasa dalam menggunakan ide mereka untuk memahami suatu konsep dalam matematika dan agar siswa maupun mahasiswa dapat belajar lebih mudah dan efektif dalam memahami suatu konsep. Tujuan utama model pembelajaran IDEA ini adalah meningkatkan dan mengembangkan pemahaman konsep. Sintaks model pembelajaran ini terdiri dari: (1) Issue, yaitu kegiatan pembelajaran untuk memunculkan ide-ide yang dimulai dengan memberikan masalah sederhana, (2) discussion, yaitu kegiatan mendiskusikan ide-ide yang digunakan untuk menyelesaikan masalah, sehingga ditemukan ide sederhana, (3) establish, yaitu kegiatan menetapkan ide sederhana yang selanjutnya dipahami sebagai suatu konsep, dan (4) apply, yaitu menerapkan konsep yang telah ditetapkan untuk menyelesaikan masalah. Dengan keempat sintaks model pembelajaran IDEA ini, diharapkan pemahaman konsep siswa maupun mahasiswa dapat meningkat atau berkembang.

Model pembelajaran IDEA yang telah berhasil didesain selanjutnya disebut sebagai prototype 1. Sebelum prototype 1 diimplementasikan, terlebih dahulu dilakukan uji validitas model pembelajaran IDEA. Uji validitas model pembelajaran IDEA ini dilakukan oleh para pakar dan praktisi. Tujuan uji validitas model pembelajaran IDEA dilakukan adalah untuk mengetahui apakah model pembelajaran IDEA ini valid atau tidak valid. Jadi tujuan penelitian ini adalah untuk mengetahui validitas model pembelajaran IDEA. 


\section{METODE PENELITIAN}

Penelitian ini merupakan penelitian pengembangan, yaitu pengembangan model pembelajaran IDEA (Issue, Discussion, Establish, and Apply). Penelitian ini dilaksanakan di Universitas Islam Malang pada bulan September sampai Desember 2019. Model pengembangan dalam penelitian pengembangan ini mengikuti prosedur pengembangan produk dari Plomp dalam (Setiawan, Sunardi, \& Kusno, 2016). Prosedur pengembangan produk dari Plomp terbagi menjadi lima tahap, yaitu: (1) tahap investigasi awal, (2) tahap desain, (3) tahap realisasi atau konstruksi, (4) tahap tes, evaluasi dan revisi, dan (5) tahap implementasi.

Tahap pertama adalah tahap investigasi awal adalah melakukan analisis terhadap kebutuhan pengembangan model pembelajaran IDEA. Hasil analisis kebutuhan pengembangan model pembelajaran IDEA antara lain: (1) masalah kesalahan di matematika sebagian besar disebabkan kurangnya pemahaman konsep, (2) sebagian besar mahasiswa masih kesulitan memahami konsep dalam matematika, (3) sebagian dosen masih kesulitan dalam membelajarkan konsep dalam matematika, (4) pembelajaran di kelas juga tidak menekankan pada pemahaman konsep, tetapi hanya menekankan pada prosedur. Implikasinya adalah dibutuhkan pengembangan model pembelajaran IDEA untuk meningkatkan atau mengembangkan pemahaman konsep.

Tahap kedua adalah tahap desain, yaitu berupa rancangan kerja yang disajikan dalam buku panduan model pembelajaran IDEA. Selanjutnya buku panduan model pembelajaran IDEA ini disebut prototype 1. Buku panduan model pembelajaran IDEA ini berisi latar belakang pengembangan model pembelajaran IDEA, teori-teori pendukung model pembelajaran IDEA, struktur model pembelajaran IDEA, desain perangkat model pembelajaran IDEA, dan implementasi model pembelajaran IDEA. Setelah berhasil mendesain model pembelajaran IDEA yang ditulis dalam bentuk buku panduan model pembelajaran IDEA, maka tahap berikutnya adalah melakukan tes, evaluasi, dan revisi terhadap model pembelajaran IDEA.

Tahap tes, evaluasi, dan revisi ini merupakan kegiatan menguji dan mengevaluasi prototype 1 yang berupa model pembelajaran IDEA. Prototype 1 yang berhasil didesain terlebih dahulu dilakukan uji validitasnya untuk mendapatkan kevalidan model pembelajaran IDEA dalam meningkatkan pemahaman Konsep. Uji validitas model pembelajaran IDEA ini dilakukan oleh 2 pakar di bidang pendidikan matematika yaitu dosen pendidikan matematika di Universitas Islam Malang dan satu praktisi, yaitu guru matematika SMA swasta.

Uji validitas dilakukan dengan meminta pakar dan praktisi untuk mengisi angket uji validitas. Angket uji validitas secara umum terdiri dari teori pendukung dan struktur model pembelajaran IDEA. Masing-masing pernyataan dalam angket menggunakan pilihan Tidak Valid (TV), Cukup Valid (CV), Valid (V), dan Sangat Valid (SV). Masing-masing pilihan diberi skor 1, 2, 3, 4. Terdapat 16 item pernyataan yang harus diisi oleh validator. Diperoleh skor minimum adalah 16 dan skor maksimum adalah 64. Dari skor minimum dan maksimum ditentukan kriteria validitas model pembelajaran IDEA dengan manggunakan interval tidak valid, cukup valid, valid, dan sangat valid. Penentuan interval tersebut menggunakan nilai kuartil, yaitu di bawah kuartil 1 tidak valid, di bawah kuartil 2 cukup valid, di bawah kuartil 3 valid, dan di atas kuartil 3 sangat valid. Diperoleh kriteria validitas model pembelajaran IDEA yang dapat dilihat dalam Tabel 1. 
Validitas Model Pembelajaran IDEA (Issue, Discussion, Establish, and Apply) untuk Meningkatkan...

Tabel 1. Kriteria Validitas Model Pembelajaran IDEA

\begin{tabular}{lll}
\hline Skor & Kategori Validitas & Keterangan \\
\hline $53-64$ & Sangat valid & Dapat digunakan tanpa revisi \\
$41-52$ & Valid & Dapat digunakan dengan revisi kecil \\
$29-40$ & Cukup valid & Dapat digunakan dengan revisi besar \\
$16-28$ & Tidak valid & Belum dapat digunakan \\
\hline
\end{tabular}

Setelah melakukan uji validitas, peneliti meminta saran untuk perbaikan model pembelajaran IDEA. Saran dari para ahli dan praktisi akan dianalisis secara kualitatif yang digunakan untuk merevisi model pembelajaran IDEA.

\section{HASIL DAN PEMBAHASAN}

Validasi model pembelajaran IDEA ini diawali dengan investigasi awal, kemudian dari hasil investigasi awal dilakukan tindak lanjut yaitu mendesain model pembelajaran IDEA. Desain model pembelajaran IDEA ini berupa buku panduan model pembelajaran IDEA yang terdiri dari: latar belakang pengembangan model pembelajaran IDEA, teori-teori pendukung model pembelajaran IDEA, dan struktur model pembelajaran IDEA. Latar belakang pengembangan model pembelajaran IDEA ini terdiri dari: hasil penelitian terdahulu, hasil penelitian pendahuluan, hasil pengkajian model pembelajaran sebelumnya, hasil angket kebutuhan model pembelajaran IDEA, dan hasil pengamatan pembelajaran di kelas. Teoriteori pendukung model pembelajaran IDEA terdiri dari: teori model pembelajaran, teori pemahaman konsep, teori terbentuknya sintaks model pembelajaran IDEA, dan teori pengembangan model pembelajaran. Sedangkan struktur model pembelajaran terdiri dari: definisi model pembelajaran, fungsi model pembelajaran, tujuan model pembelajaran, fokus model pembelajaran, sintaks model pembelajaran, prinsip-prinsip reaksi, sistem sosial, sistem pendukung, penerapan dan dampak model, evaluasi dan penilaian, serta hasil belajar yang dinginkan.

Setelah buku panduan model pembelajaran berhasil didesain. Maka langkah berikutnya adalah melakukan uji validitas secara teoritis dari model pembelajaran IDEA yang telah berhasil di desain. Uji validitas dilakukan oleh 2 orang dosen, yaitu dosen pendidikan matematika di Universitas Islam Malang. Selain itu uji validitas dilakukan oleh satu guru mata pelajaran matematika yang mengajar di jenjang SMA. Hasil validasi model pembelajaran IDEA oleh 2 orang dosen dan 1 guru dapat dilihat dalam Tabel 2.

Tabel 2. Hasil Validasi Model Pembelajaran IDEA oleh 2 dosen (I dan II) dan 1 guru (III)

\begin{tabular}{llll}
\hline \multirow{2}{*}{ Aspek yang dinilai } & \multicolumn{3}{l}{ Validator } \\
\cline { 2 - 4 } & I & II & III \\
\hline Teori pendukung model pembelajaran IDEA: & & & \\
& & & \\
\hline $\begin{array}{l}\text { Teori model pembelajaran yang digunakan untuk } \\
\text { mengembangkan model pembelajaran IDEA telah sesuai. }\end{array}$ & 4 & 4 & 4 \\
$\begin{array}{l}\text { Teori pemahaman konsep yang akan dibangun oleh } \\
\text { model pembelajaran IDEA telah tercakup dalam model } \\
\text { pembelajaran IDEA. }\end{array}$ & 4 & 4 & 4
\end{tabular}




\begin{tabular}{|c|c|c|c|}
\hline \multirow{2}{*}{ Aspek yang dinilai } & \multicolumn{3}{|c|}{ Validator } \\
\hline & I & II & III \\
\hline $\begin{array}{l}\text { Teori terbentuknya sintaks model pembelajaran IDEA telah } \\
\text { sesuai dengan sintaks model pembelajaran IDEA. }\end{array}$ & 3 & 3 & 4 \\
\hline $\begin{array}{l}\text { Teori pengembangan model pembelajaran telah sesuai } \\
\text { dengan teori Plomp. }\end{array}$ & 4 & 4 & 4 \\
\hline
\end{tabular}

Struktur model pembelajaran IDEA:

\begin{tabular}{llll}
\hline Definisi model pembelajaran IDEA dinyatakan secara jelas. & 4 & 4 & 4
\end{tabular}

Fungsi model pembelajaran IDEA dinyatakan secara jelas. $\quad \begin{array}{llll}3 & 3 & 4\end{array}$

Tujuan model pembelajaran IDEA dinyatakan secara jelas $\quad \begin{array}{lll}3 & 3\end{array} 4$

$\begin{array}{lllll}\text { Fokus model pembelajaran IDEA dinyatakan secara jelas } & 4 & 3 & 4\end{array}$

Sintaks model pembelajaran IDEA dinyatakan secara jelas $\quad \begin{array}{lll}3 & 3\end{array} 4$

Prinsip-prinsip reaksi model pembelajaran IDEA dinyatakan $\begin{array}{llll}4 & 3 & 4\end{array}$

secara jelas dan dapat digunakan.

Sistem sosial model pembelajaran IDEA dinyatakan secara $\quad \begin{array}{llll}4 & 3 & 4\end{array}$ jelas

Sistem pendukung model pembelajaran dapat dipenuhi. $\quad \begin{array}{llll}4 & 3 & 4\end{array}$

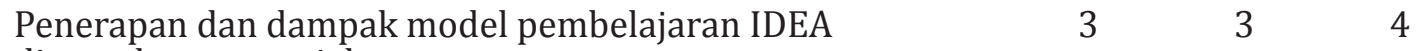
dinyatakan secara jelas.

Evaluasi dan penilaian dinyatakan secara jelas dan terukur. $\begin{array}{llll}3 & 3 & 3\end{array}$

$\begin{array}{llll}\text { Hasil belajar yang dinginkan dinyatakan secara jelas. } & 3 & 3 & 3\end{array}$

$\begin{array}{llll}\text { Perangkat pembelajaran telah sesuai dengan model } & 3 & 3 & 3\end{array}$ pembelajaran IDEA.

\begin{tabular}{llll}
\hline Jumlah & 56 & 52 & 61
\end{tabular}

$\begin{array}{lll}\text { Keterangan } & \text { Sangat Valid } & \text { Sangat } \\ \text { Valid }\end{array}$


Setelah memberikan skor dari masing-masing item. Validator diminta untuk memberikan keputusan. Validator I, II, dan III memberikan keputusan bahwa model dapat digunakan dengan sedikit revisi. Ini artinya bahwa model pembelajaran IDEA valid dan membutuhkan revisi. Revisi model pembelajaran IDEA dilakukan dengan mempertimbangkan saran-saran yang diberikan oleh validator. Saran dari masing-masing validator dan hasil revisi dapat dilihat dalam Tabel 3.

Tabel 3. Saran dan Revisi Prototipe 1 Model Pembelajaran IDEA

\begin{tabular}{|c|c|c|}
\hline Validator & Saran & Revisi \\
\hline I & $\begin{array}{l}\text { Ada beberapa proses } \\
\text { kegiatan yang kurang } \\
\text { jelas untuk mahasiswa, } \\
\text { terutama pada bagian issue, } \\
\text { hendaknya diperjelas bentuk } \\
\text { kegiatan belajar mahasiswa } \\
\text { untuk menemukan ide-ide. }\end{array}$ & $\begin{array}{l}\text { Memperjelas kegiatan yang dilakukan oleh } \\
\text { mahasiswa pada tahap issue, yaitu untuk } \\
\text { menemukan ide-ide, antara lain: } \\
\text { Dosen memberikan masalah sederhana. } \\
\text { Mahasiswa diminta untuk menyelesaikan } \\
\text { masalah sederhana tersebut. } \\
\text { Mahasiswa diminta untuk mencatat cara-cara } \\
\text { yang mereka gunakan. }\end{array}$ \\
\hline II & $\begin{array}{l}\text { Teori yang mendasari sintaks } \\
\text { hendaknya dinyatakan } \\
\text { secara jelas dan alasan } \\
\text { terbentuknya sintaks }\end{array}$ & $\begin{array}{l}\text { Memberikan penjelasan di masing- } \\
\text { masing sintaks dengan teori belajar yang } \\
\text { melandasi terbentuknya sintaks serta alasan } \\
\text { membentuk sintaks model pembelajaran } \\
\text { IDEA. }\end{array}$ \\
\hline III & $\begin{array}{l}\text { Sistem pendukung model } \\
\text { pembelajaran seperti } \\
\text { penilaian hasil belajar masih } \\
\text { belum memiliki pedoman } \\
\text { penskoran. }\end{array}$ & $\begin{array}{l}\text { Membuat pedoman penskoran untuk } \\
\text { penilaian hasil belajar. }\end{array}$ \\
\hline
\end{tabular}

Saran darivalidator digunakan untukmerevisi modelpembelajaran IDEAini.Selanjutnya, hasil revisi dari model pembelajaran IDEA berdasarkan masukan para validator dikonsultasikan kembali kepada validator. Hasil konsultasi kembali telah menunjukkan bahwa validator I, II, dan III mengatakan bahwa model pembelajaran IDEA untuk meningkatkan pemahaman konsep telah valid dan dapat dilakukan uji coba untuk model pembelajaran IDEA.

Berdasarkan hasil uji validitas dapat diketahui bahwa model pembelajaran IDEA valid artinya telah sesuai dengan teori model pembelajaran. Model pembelajaran IDEA ini telah memenuhi syarat model pembelajaran yang baik menurut (Joyce, Weil, \& Calhoun, 2015), yaitu harus memiliki fokus, sintaks, prinsip-prinsip reaksi, sistem social, sistem pendukung, penerapan dan dampaknya. Selain itu model pembelajaran IDEA ini valid untuk meningkatkan pemahaman konsep. Validitas model pembelajaran IDEA ini dalam meningkatkan pemahaman konsep menggunakan model pencarian konsep yang berorientasi seleksi, yaitu menempatkan tanggung jawab pencarian konsep dan pelacakan atribut dilakukan oleh mahasiswa sendiri. Dimana ada tiga model pencarian konsep, yaitu model pencarian konsep berorientasi penerimaan, model pencarian konsep berorientasi seleksi, dan model pencarian konsep yang tidak terorganisir (Joyce, Weil, \& Calhoun, 2015). Validitas model pembelajaran IDEA ini telah memuat kegiatan untuk mendukung pemahaman konsep dalam setiap sintaksnya. Jadi validitas model pembelajaran IDEA ini antara lain: sesuai dengan syarat model pembelajaran yang baik, mampu meningkatkan pemahaman konsep dengan berorientasi pada model pencarian konsep, dan memuat indikator-indikator pemahaman konsep dalam setiap sintaknya. 


\section{SIMPULAN DAN SARAN}

Berdasarkan hasil penelitian dan pembahasan di atas dapat disimpulkan bahwa model pembelajaran IDEA dinyatakan valid, sehingga model pembelajaran IDEA ini dapat diimplementasikan untuk meningkatkan atau mengembangkan pemahaman konsep. Penelitian selanjutnya adalah melakukan uji coba lapangan untuk kelompok kecil dan ujicoba untuk kelompok besar satu kelas untuk mendapatkan masukan-masukan dari para pengguna termasuk mahasiswa, dosen, siswa, atau guru.

\section{DAFTAR RUJUKAN}

Adna, S. F. (2017). Deskripsi tipe kesalahan mahasiswa dalam uas mata kuliah statistika penelitian pendidikan. Delta: Jurnal Ilmiah Pendidikan Matematika, 5(2), 29-36. doi: 10.31941/delta.v5i2.553

Adna, S. F. (2017). Deskripsi tipe kesalahan mahasiswa dalam uas mata kuliah statistika penelitian pendidikan. Delta: Jurnal Ilmiah Pendidikan Matematika, 5(2), 29-36.

Afifah, D. S. N., Nafi'an, M. I., \& Putri, M. I. (2018). Analisis Kesalahan Mahasiswa Dalam Menyelesaikan Soal Kalkulus Peubah Banyak. MaPan: Jurnal Matematika Dan Pembelajaran, 6(2), 207-220. doi: 10.24252/mapan.2018v6n2a7

Afriadi, J. (2019). Identifikasi Kesalahan dan Miskonsepsi Mahasiswa Calon Guru Matematika Pada Topik SPLDV. Math Educa Journal, 2(2), 231-243. doi: 10.15548/mej.v2i2.191

Arvianto, I. R. (2017). Kesalahan Mahasiswa Dalam Menyelesaikan Soal Integral Berdasarkan Gaya Kognitif. Jurnal Matematika Dan Pendidikan Matematika, 2(1), 36-47.

Fachrurrozy, M., Muslimin, \& Saehana, S. (2017). Program Studi Pendidikan Fisika ( Studi Kasus Pada Materi Kinematika Dengan Analisis Vektor ). E-Jurnal Mitra Sains, 5(2), $1-10$.

Farhan, M., \& Zulkarnain, I. (2019). Analisis Kesalahan Mahasiswa pada Mata Kuliah Kalkulus Peubah Banyak Berdasarkan Newmann' s Error Analysis. Jurnal Kajian Pendidikan Matematika, 4(2), 121-134.

Jana, P. (2018). Analisis Kesalahan Mahasiswa Dalam Menyelesaikan Soal Matematika Pada Pokok Bahasan Vektor. Jurnal Mercumatika : Jurnal Penelitian Matematika Dan Pendidikan Matematika, 2(2), 8. doi: 10.26486/jm.v2i2.398

Joyce, B., Weil, M., \& Calhoun, E. (2015). Models of Teaching (9th ed.). London, England: Pearson Education.

Lembang, S. T., \& Ba'ru, Y. (2018). Analisis Kesalahan Mahasiswa dalam Menyelesaikan Soal Aljabar Linier Pada Materi Sistem Persamaan Linier. Jurnal KIP, 6(3), 249-256.

Lusiana, R. (2017). Analisis Kesalahan Mahasiswa Dalam Memecahkan Masalah Pada Materi Himpunan Ditinjau Dari Gaya Kognitif. Jurnal Penelitian Dan Pembelajaran Matematika, 10(1), 24-29. doi: 10.30870/jppm.v10i1.1290

Mills, J. (2019). Making Multiplication Meaningful: Teaching for Conceptual Understanding. Teachers and Curriculum, 19(1), 17-25. doi: 10.15663/tandc.v19i1.334

Oktaviana, D. (2018). Analisis Tipe Kesalahan Berdasarkan Teori Newman Dalam Menyelesaikan Soal Cerita Pada Mata Kuliah Matematika Diskrit. Edu Sains: Jurnal Pendidikan Sains \& Matematika, 5(2), 22. https://doi.org/10.23971/eds.v5i2.719

Rosmaiyadi. (2018). Analisis Kesalahan Penyelesaian Soal Aljabar pada Mahasiswa Program Studi Pendidikan Matematika STKIP Singkawang. Journal Pendidikan Matematika, 12(1), 59-70.

Setiawan, Y. E. (2015). Analisis Domain dan Dampak Mathematical Knowledge for Teaching Terhadap Pengajaran. In Hobri (Ed.), Reformasi Pendidikan dalam Memasuki ASEAN Economic Community (AEC). Jember: FKIP Universitas Jember. 
Setiawan, Y. E. (2019). Peta Konsep dalam Pembelajaran Matematika. Lumajang: AL-Mukmin Yes.

Setiawan, Y.E., Sunardi, \& Kusno. (2016). Pengembangan Paket Tes Geometri untuk Mengukur Keterampilan Berpikir Kritis. In G. Muhsetyo, E. Hidayanto, \& R. Rahardi (Eds.), Prosiding Seminar Nasional Pendidikan Matematika dengan tema "Pengembangan 4C's dalam Pembelejaran Matematika: Sebuah Tantangan dalam Pengembangan Kurikulum Matematika". Malang, Indonesia: Bintang Sejahtera.

Setiawan, Y. E., Purwanto, Parta, I. N., \& Sisworo. (2020). Generalization Strategy of Linear Patterns From Field-Dependent Cognitive Style. Journal on Mathematics Education, 11(1), 77-94. doi: 10.22342/jme.11.1.9134.77-94 